\title{
Trondenes Seminarium: Et lærdomsmiljø grunnlegges
}

\author{
LIV HELENE WILLUMSEN *
}

\section{Keywords}

Nineteenth century, teacher training, catechism education, northern Norway, elementary schools

1800-tallet, lærerutdannelse, kateketutdannelse, Nord-

Norge, folkeskole

\begin{abstract}
Trondenes Teacher Training Institute: The Creation of an Educational Environment

The present article investigates the foundation of the very first governmentfinanced teacher training institute in Norway, Trondenes Seminarium. Established in 1826 in northern Norway, its aim was to train primary school teachers and catechists for the northernmost areas of the country, in response to the growing demand for qualified elementary school teachers. Discussing central factors related to the decision to locate this institution in the north, the article highlights the debate in the National Assembly and the interaction between central and regional levels within the national educational system. In addition, its first years of operation are examined, indicating the challenges met by the fledgling institute. As a micro-study, the article sheds light on some connections between regional and central factors, emphasizing the interplay between the state and the church during the early development of the Norwegian primary school system.
\end{abstract}

To cite this article

Liv Helene Willumsen, “Trondenes Seminarium: Et lærdomsmiljø grunnlegges,” Nordic Journal of Educational History 1, no. 1 (2014), pp. 45-58.

\section{Innledning}

Året 1826 var for første gang lærerutdanning i Norge et offentlig anliggende. Da landets første offentlige lærerutdanning var en realitet, var navnet Trondenes Seminarium, og lokaliseringen var Trondenes prestegjeld i Nord-Norge, like ved en kjent og ærverdig middelalderkirke. ${ }^{1}$ I denne artikkelen vil jeg rette søkelyset mot noen faktorer som var avgjørende for denne opprettelsen og mot noen sentrale forhold ved institusjonens lærdomsmiljø de første år.

Problemstillingen som tas opp til drøfting i artikkelen knytter seg til interaksjonen mellom de nasjonale og de regionale nivåer i denne tidlige fasen av utdanningshistorien: Hvordan kan en mikrostudie av Trondenes Seminarium, med særlig vektlegging av de diskusjoner som foregikk i Stortinget før oppstart av institusjonen, kaste lys over den relative betydning av sentrale og lokale nivåer som var aktivert $\mathrm{i}$ prosessen? Ett forskningsspørsmål knyttet til denne problemstillingen er hvorvidt

\footnotetext{
* Professor of History, Department of History and Religious Studies, University of Tromsø. Email: liv.willumsen@uit.no.

Jeg vil gjerne takke Fondet for dansk-norsk samarbeid for stipendiatopphold på Schæffergaarden i København i forbindelse med kildestudier til denne artikkelen.

${ }^{1}$ Forhandlingsprotokoll Trondenes Skolelærerseminarium og Tromsø Seminar 1826-1863, løpenummer 1, Tromsø offentlige lærerskoles arkiv (TOLA), Statsarkivet i Tromsø (SATØ).
} 
stortingsvedtaket om igangsetting av Trondenes Seminarium kan belyse styrkeforholdet mellom statlig implementerte intensjoner og bestemmelser og tilsvarende ambisjoner fra lokalt hold. Et annet forskningsspørsmål dreier seg om hvordan det faktiske læringsmiljøet som utviklet seg de første årene ved Trondenes Seminarium forholdt seg til de mål som var nedfelt i Stortingets vedtak om opprettelse av denne lærerutdanningen.

Av tidligere forskning på Norges første lærerutdanning bør nevnes særlig Mary Brekkes doktoravhandling Lærerutdanning i Nord: Et historisk kasus gjennom tre tidsperioder. ${ }^{2}$ I denne avhandlingen er et kapittel viet Trondenes Seminarium i perioden 1826-1848, og en verdifull drøfting er foretatt ut fra primærkildemateriale. 3 De spørsmål som tas opp i denne artikkelen bygger ut og konkretiserer den nevnte avhandlingens funn ved nærlesning av de preliminære drøftinger på Stortinget som førte til vedtak om oppstart av Trondenes Seminarium. I tillegg vil denne artikkelen i større grad enn tidligere forskningsarbeider belyse hvordan igangsetting av Norges første lærerutdanning var beroende av sentrale føringer preget av datidens pedagogiske europeiske strømninger.

Artikkelen er tredelt: For det første en redegjørelse for seminarets forhistorie og den diskusjonen som foregikk på Stortinget i Norge 1817-1824 før bestemmelsen om oppstart av lærerutdanning på Trondenes ble fattet. For det andre en drøfting av Stortingets vedtak om igangsetting av Trondenes Seminarium og de premisser som ble lagt til grunn for dette vedtaket. For det tredje en presentasjon av lærdomsmiljøet ved Trondenes Seminarium de første årene institusjonen eksisterte med henblikk på lærere, elever, fag, økonomiske forhold og praktisk ramme. Til slutt vil jeg gi en kort vurdering av seminarets første år sett i lys av institusjonens videre utvikling.

\section{De tidlige seminarer i Trondheim på 17oo-tallet}

Oppstarten av Trondenes Seminarium må sees i lys av den interesse og det behov som eksisterte i Norge for etablering av et konsistent skolevesen etter 1814, da Norges union med Danmark opphørte. En viktig brikke i dette bildet var utdannelse av lærere, og denne problematikken kom med stor styrke opp til drøfting på Stortinget i perioden 1817-1824. Tiden for etablering av norsk lærerutdanning var moden ut fra pedagogisk og ideologisk grunnlag. Internasjonale pedagogiske strømninger spilte med når det gjaldt etableringen av lærerutdanning i Norge. Disse ideene kom til Norge særlig via Blaagaard Seminarium i Danmark, den første nordiske lærerutdanningsinstitusjon etablert i 1792.4 Tone Skinningsrud peker i sin doktoravhandling Fra reformasjonen til mellomkrigstiden: Framveksten av det norske utdanningssystemet på betydningen av europeisk idéhistorisk påvirkning både for etablering av Blaagaard Seminarium og Brahetrolleborg Seminarium, som også ble etablert før år 180o.5

\footnotetext{
2 Mary Brekke, Lærerutdanning i Nord: Et historisk kasus gjennom tre tidsperioder (Luleå: Luleå tekniska universitet, 2000).

3 Brekke (2000), 25-81.

4 I Sverige ble det første folkeskoleseminarium opprettet i Lund og startet i 1839. På Island ble den første lærerskolen etablert i Reykjavik i 1908 og Finland fikk sitt første seminarium i 1921. Randi Skjelmo, "Utdanning av lærere for det nordlige Norge før 1826: Tidlige nordiske institusjoners betydning som forløpere for offentlig lærerutdanning," i Norrlandsfrågan: Erfarenheter av utbildning, bildning och fostran i nationalstatens periferi, red. Johannes Westberg och David Sjögren (Stockholm, 2014, kommer).

5 Tone Skinningsrud, Fra reformasjonen til mellomkrigstiden: Framveksten av det norske utdanningssystemet (Tromsø: Universitetet i Tromsø, 2013), 339-43, 462-64.
} 
Forhistorien til seminaret på Trondenes må knyttes til 1700-tallets arbeid med misjon og utdannelse for den samiske befolkningen i nordlige Norge. På begynnelsen av 1700-tallet var misjon og skole uløselig forbundet, noe som er understreket i Anton Hoëms studie Fra Noaidiens verden til forskerens: Misjon, kunnskap og modernisering $i$ sameland $1715^{-2007.6}$ Kong Frederik IVs interesse for misjon førte til opprettelsen av en institusjon kalt Missionskollegiet i København den 10. desember 1714. ${ }^{7}$ Institusjonen skulle virke for misjon blant samene i Norge, som bodde i Finnmark og i Trøndelag. Missionskollegiet kom også til å drive misjon i Trankebar i India og på Grønland. Med hensyn til det økonomiske disponerte kollegiet egne midler bestående av en engangsbevilgning fra kongen samt midler tilhørende kirkene i Finnmark. Midler fra Missionskollegiet skulle komme til å legge grunnlaget for opprettelsen av tre seminarier i Trondheim, det gamle erkebiskopsetet i Norge. Disse institusjonene var kalt Seminarium Scolasticum, Seminarium Domesticum og Seminarium Lapponicum. ${ }^{8}$ Seminarene hadde som oppgave å utdanne misjonærer og lærere som skulle virke blant den samiske befolkningen. Thomas von Westen, kalt Samenes Apostel, underviste ved de to førstnevnte seminarene. ${ }^{9}$ Rundt 1800 ble Missionskollegiets misjonsvirksomhet blant samene i Norge avsluttet. I 1802 ble kollegiet "lettet" for dette arbeidet. Imidlertid fortsatte misjonsarbeidet på Grønland og i Trankebar. Pengene som fra Missionskollegiets side var intendert for misjon i Norge, og var knyttet til driften av Seminarium Lapponicum i Trondheim, ble stående i et "sovende" fond, Seminarii Lapponici Fond. ${ }^{10}$ Ingen forandringer ble gjort i statuttene, noe som betydde at fondets midler fremdeles skulle brukes til arbeid for opplysning blant den samiske befolkningen. Dette fondet kom til å få en direkte betydning for oppstarten av Trondenes Seminarium.

\section{Diskusjoner på Stortinget 1817-1824}

Går man videre til årene like før Trondenes Seminarium kom i gang, er det naturlig å se på de diskusjoner som foregikk på det norske Stortinget og rette søkelyset mot de argumentene som da ble brakt på banen. Det første forslaget om lærerutdanning nord i landet kom i 1817, etter initiativ fra geistlig hold. Peter Vogelius Deinboll, prest i Vadsø i Norge, satte fram forslag gjennom Finmarkens amt om oppstart av et seminar for lærere med lokalisering Vadsø i Øst-Finnmark. ${ }^{11}$ Deinboll var opprinnelig dansk og kom til Øst-Finnmark i 1816 etter å ha tatt teologisk embetseksamen ved det nylig opprettede universitet i Norges hovedstad. Han viste umiddelbart stor interesse for utvikling av skolevesenet i Finnmark, som han mente var meget tilbakeliggende. Det var spesielt den samiske folkegruppens situasjon han var opptatt av. Deinboll ble prost i Finnmark og valgt inn som representant for Finmarkens amt til Stortinget i 1821 og

\footnotetext{
6 Anton Hoëm, Fra noaidiens verden til forskerens: Misjon, kunnskap og modernisering i sameland 17152007 (Oslo: Novus forlag, 2007), 72.

7 Hoёm (2007), 83 .

8 Skjelmo (2014).

9 Randi Skjelmo, "Utdanning av lærere for det nordlige Norge: De tidlige institusjoner i Trondheim 1717-1732," Sjuttonhundratal: Nordic Yearbook for Eighteenth-Century Studies (2013), 39.

${ }^{10}$ Liv Helene Willumsen, "Økonomiske vilkår for lærerutdanning i nordlige Norge: Den historiske utvikling av Seminarii Lapponici Fond” i Norrlandsfrågan: Erfarenheter av utbildning, bildning och fostran $i$ nationalstatens periferi, red. Johannes Westberg och David Sjögren (Stockholm, 2014, kommer).

${ }^{11}$ Helge Dahl, Tromsø offentlige lærerskole i 150 år: 1826-1976. Jubileumsskrift (Tromsø: AS Peder Nordbyes trykkeri, 1976), 9-10.
} 
1824. Der ble han foregangsmann for saken om etablering av lærerutdanning i det nordlige Norge. Året etter det første forslaget, som gikk inn for å legge institusjonen til Vadsø, kommer det fram gjennom korrespondanse med biskopen i Nordlandene og Finmarken, Mathias Bonsach Krogh, ${ }^{12}$ at Deinboll kan tenke seg andre nordnorske lokaliseringer, med begrunnelse i Vadsøs perifere beliggenhet. Både Talvik, som lå ved Alta i Finnmark, og senere Tromsø, var stedsnavn som ble nevnt. Men hele tiden var det snakk om en plassering av seminaret i Nord-Norge. ${ }^{13}$

Arbeidet med saken om lærerutdanning ble intensivert på Stortinget de første årene av 1820-tallet, da Deinboll stilte seg i spissen for et omfattende arbeid med å få planene realisert. I 1821 satte Deinboll gjennom brev til Odelstinget fram forslag om opprettelse av et "Incrementfond" til et skolelærerseminarium i Tromsø for Norges to nordligste amt. ${ }^{14}$ Forslaget ble sendt over til "Comitéen angaaende Almue-Skolevæsenet", som Deinboll var medlem av. ${ }^{15}$ Deinboll satte så fram forslag i Stortinget om "Opprettelse af et Skolelærerseminarium for Nordlands og Finmarkens Amter", de to nordligste amt i Norge. Den anbefalte komitéinnstillingen ble vedtatt, samtidig som det ble bestemt at midlene fra Seminarii Lapponici Fond skulle anvendes til den foreslåtte læreanstalt. Dette fondet tilhørte 1700-tallsinstitusjonen Seminarium Lapponicum, hvis drift var opphørt. Fondet viste seg å være av interesse både fordi det hadde en viss kapital, fordi det hadde en spesiell målsetting og fordi det på det daværende tidspunkt ble brukt til ulike oppgaver som ikke direkte hadde med dets intensjon å gjøre. Det var egentlig opprettet for at det skulle drives misjon i Nord-Norge, men var etter 1800 anvendt blant annet til pensjon og liknende formål til dels utenfor Nord-Norge. Nå viste det seg at fondets midler kunne anvendes i en aktuell situasjon. Det økonomiske bidrag som dette fondet kunne gi, skulle vise seg å bety en finansiell løsning for etablering av den første offentlige norske lærerutdanning. Fondets målsetting kunne nemlig kombineres med oppstart av et lærerutdanningsseminar i nordlige Norge, der målet var å utdanne lærere og kateketer for virke i nord. Følgen var at fondets midler kunne frigis til etablering av seminaret og denne økonomiske basis ble brukt som argument for å få etableringen vedtatt i de nødvendige offentlige organer. Vedtaket om opprettelse av seminaret fikk kongelig sanksjon i august $1821 .^{16}$ I mai 1822 ble kongelig resolusjon tatt til følge. ${ }^{17}$ Den endelige lokaliseringen, Trondenes, ble ikke kunngjort før to år senere. I juni 1824 ble det bestemt ved kongelig resolusjon at seminaret skulle anlegges i Trondenes prestegjeld og at det skulle treffes beslutninger om anstaltens ordning. Det ble opplyst at Seminarii Lapponici Fond stod klar til å bestride utgiftene fra 1. januar $1825 \mathrm{og}$ at åpningen skulle skje 1 . juli $1825 \cdot{ }^{18} \mathrm{Og}$ åpningen fant sted, selv om den skjedde med noen måneders forsinkelse, nemlig i begynnelsen av 1826.

Det er hevet over tvil at Peter Vogelius Deinboll gjorde en stor innsats på Stortinget for å få opprettet seminaret. Han må imidlertid ha hatt flere innflytelsesrike

\footnotetext{
12 Mathias Bonsach Krogh (1754-1828), norsk geistlig. Han var oppvokst i Nord-Norge, og ble sogneprest i Lenvik, Vågan og Ørlandet før han ble utnevnt som biskop. Han skrev avhandling om Universitetet i 1810.

13 Brev fra Deinboll til biskop Mathias Bonsach Krogh av 23. nov. 1818, Brev til embetsmenn, Biskopen i Tromsø Stifts arkiv (BTSA), SATØ.

14 Stortingsarkivet, 31 . mai 1821, forslag til Odelstinget.

15 Stortingsarkivet, 14. april 1821; Dahl (1976), 10.

16 Stortingsarkivet, 9. august 1821, 11. august 1821; Dahl (1976), 11.

17 Stortingsarkivet, 4. mai 1822.

18 Stortingsforhandlinger, Kgl. Res. 2. juni 1824.
} 
støttespillere. Ikke minst biskop Mathias Bonsach Krogh, som bodde på Alstadhaug på Helgeland, et godt stykke sørover langs kysten fra både Finnmark og Tromsø, var en viktig støtte i arbeidet for etablering av institusjonen. Krogh var opptatt av skolevesenet og påvirket trolig plasseringen av skolelærerseminaret på Trondenes. ${ }^{19}$ Deinboll hadde et tillitsfullt forhold til biskopen og korresponderte flittig med ham. ${ }^{20}$ Men det var ikke nok med visjoner, idealisme og pågangsmot. Konkrete utfordringer måtte løses. Blant annet måtte finansieringen på plass. Seminarii Lapponici Fond kom på en gunstig måte inn i bildet for forkjemperne for seminaret, som en konkret mulighet for å realisere planene fordi fondet hadde som målsetning å arbeide for opplysning og skolegang i det nordlige Norge, særlig blant den samiske befolkning. Antakelig er anvendelsen av dette fondet svaret på hvorfor den første norske lærerutdanningen ble plassert i de nordlige egne.

Overraskende for mange er det faktum at den første offentlige lærerutdanning i Norge ikke ble plassert i området rundt hovedstaden. Her har tilgang til økonomiske midler spilt en viktig rolle. For at forslaget om lærerutdanning på Trondenes skulle gå gjennom i Stortinget, var det nødvendig å finne en løsning på det økonomiske. Man trengte en garanti ved seminarets åpning for at det økonomiske ville bli ivaretatt. Men dette førte også med seg at noen premisser ble lagt for institusjonens profil. I Deinbolls forslag fra 1821 var det en bestemmelse om at Finnmark prosti skulle få inn en ekstra kvote av samisktalende elever. Dessuten trengtes en lærer som benyttet det samiske språk, for at samiske elever skulle få sin undervisning og bli skikket til å gå ut som lærere for den samiske befolkning. ${ }^{21}$ Dette imøtekom Seminarii Lapponici Fonds opprinnelige vektlegging av opplysningsarbeid blant samene. Det var derfor strategisk klokt av Deinboll å tydeliggjøre inntaket av samiske elever til Trondenes Seminarium. Denne faktoren ble da også helt avgjørende for det særpreg Trondenes Seminarium fikk som utdanningsinstitusjon, noe som er påpekt av Mary Brekke. ${ }^{22}$ Riktignok la lærerutdanningen på Trondenes også til rette for inntak av norske elever, men midler øremerket disse var vanskeligere å få tak i. Det er tydelig at konkrete praktiske vilkår er vektlagt under argumentasjonen i Stortinget for etablering av lærerutdanning i det nordlige Norge. Likevel er det grunn til å understreke at de argumenter og føringer som ligger til grunn for at saken om oppstart av lærerutdanning i nord kom opp med tyngde på Stortinget, er knyttet til mentalitetshistoriske forhold i Danmark og andre europeiske land, der betydningen av kunnskap og opplysning for alle var kjernepunktet og drivkraften i det som ble ansett som nødvendig, nemlig lærerutdanning basert på statlig ansvar.

\section{Virksomheten ved Trondenes Seminarium de forste årene}

De første årenes virksomhet ved Trondenes Seminarium kan belyses både gjennom primærkilder, nemlig forhandlingsprotokoll og institusjonens arkivmateriale for øvrig, gjennom jubileumsskrifter forfattet til institusjonens 50, 100 og 150-årsjubiléer,

\footnotetext{
19 Tarald Rasmussen, "Mathias Bonsach Krogh,” Store norske leksikon, nettutgave, nedlastet 20.01.2011.

20 Brev til embetsmenn, Korrespondanse mellom Deinboll og biskop Mathias Bonsach Krogh 1816-1825, BTSA, SATØ.

21 "Sagen om Seminarium Lapponicum og Trondenæs Skolelærerseminarium", brev til Norges Odelsthing fra Deinboll datert 31. mars 1821, Kontoret for kirke og geistlighet A 1821-1835, eske 986, Kirke- og Undervisningsdepartementets arkiv (KUDA), Riksarkivet (RA).

22 Brekke (2000), 34.
} 
gjennom Chritian Wiigs bok Tromsø-seminarister samt gjennom studier som eksempelvis Mary Brekkes avhandling. ${ }^{23}$

BILDE 1. Første referat innført i forhandlingsprotokoll Trondenes Seminarium, 1826

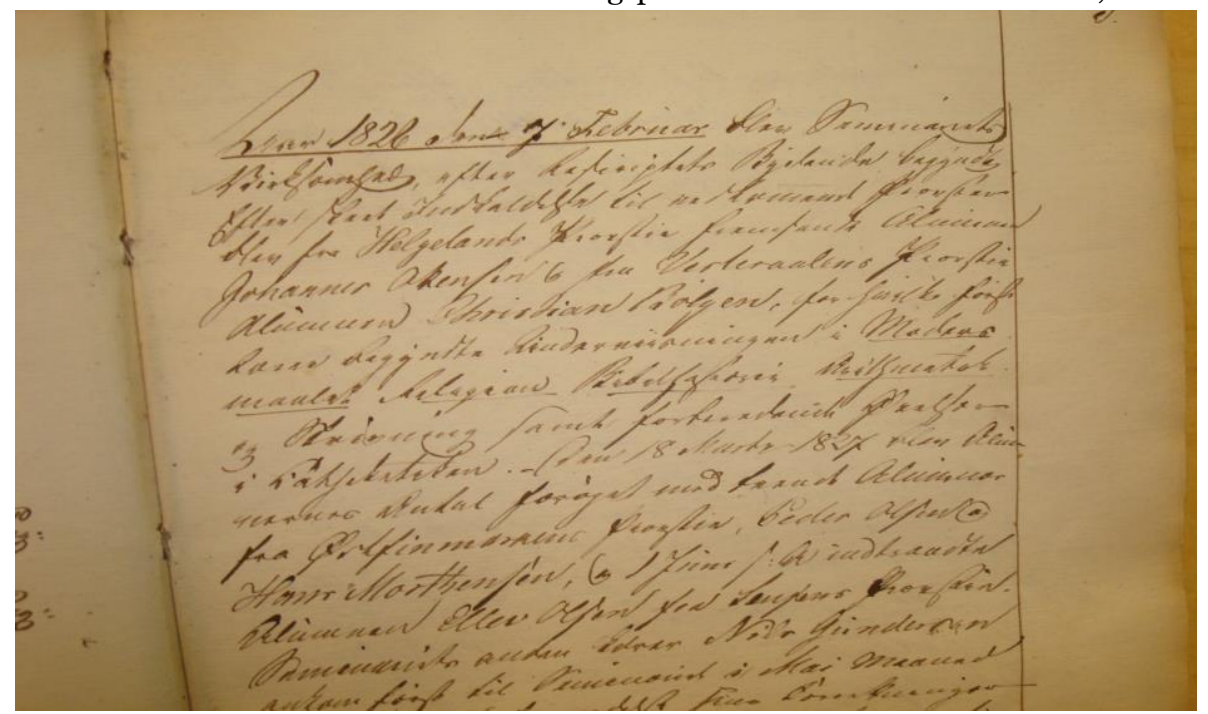

Kilde: Statsarkivet i Tromsø, Tromsø offentlige lærerskoles arkiv

Bestemmelsene om inntak var viktige for virksomheten ved Trondenes Seminarium de første årene. Det skulle tas opp ni elever, eller Alumner, fra bispedømmet. Av disse skulle to komme fra Øst-Finnmark prosti; en samisk og en norsk. Fra Vest-Finnmark tilsvarende to elever; en samisk og en norsk. Ellers skulle det komme en elev fra hvert prosti. De skulle velges ut av prosten. Elevene fikk reisepenger fra hjemstedet til Trondenes tur-retur samt oppholdsutgifter mens de bodde på seminaret. Enkelte bygder ble tillatt å holde elever på egen bekostning.

De første årene var det to lærere ansatt ved seminaret. Bestyrer og førstelærer var Simon Nicolai Kildal. Han var prost og sogneprest i Trondenes. Kildal fikk ikke ekstra betalt for sin undervisning ved seminaret. Da det ble klart at seminaret kom til å bli lagt til Trondenes og sogneprestembetet der stod ledig etter daværende prost Simon Kildals død i 1822, ble det til embetet knyttet det vilkår at den nye sognepresten hadde plikt til å overta undervisningen og de øvrige forretninger ved seminaret. Han var "ifølge sit Kaldsbrev forpligtet til at overtage Undervisningen og øvrige Forretninger uden Godtgjørelse”. ${ }^{24}$ Kildal skulle også overta kasserens oppgaver for Seminarii Lapponici Fond når den daværende kassereren gikk av. Han måtte skjøtte sine geistlige forretninger ved siden av arbeidet ved seminaret. I tillegg var han valgt stortingsmann i 1827, 1829 og 1830, og var da borte fra Trondenes 2 til 3 måneder hvert år. Totalt sett

23 J. Killengreen, Beretning om Tromsø Seminarium meddelt ved Seminariets halvhundreaarsfest den 7 de Februar 1876 (Tromsø: Carl Hansens Bogtrykkeri, 1876); K. J. Barlindhaug, Tromsø offentlige lærerskole i 100 år (Tromsø: AS Peder Norbyes bok \& aksidenstrykkeri, 1926); Dahl (1976); Christian Wiig, Tromsøseminarister: Biografiske oplysninger om seminarister som er dimittert fra (Trondenes og) Tromsø seminar, 1829-1879 (Oslo: Land og kirke, 1948); Brekke (2000), 25-81.

24 Brev datert 18. juni 1824 fra Trescow, Kirke- og Undervisningsdepartementet, til politimester Lie, Seminari Lapponici Fonds arkiv (SLFA), Statsarkivet i Trondheim (SAT). 
var det en meget krevende arbeidsoppgave han var blitt stilt overfor etter at seminaret var blitt etablert. Bestyrer Kildal døde i 1837, bare 41 år gammel. Trolig var arbeidspresset en medvirkende årsak til at han gikk tidlig bort.

Annenlærer var Nils Gundersen fra Finnmark. Han var samisk, født i Tana i 1771.25 Han hadde vært lærer i Måsøy i Finnmark i 35 år, der han underviste samiske barn. Gundersen ble ansatt ved Trondenes Seminarium i mai 1827 og underviste de elevene som hadde samisk som morsmål. Lønn til Gundersen var årlig på 200 speciedaler, "foruden frit Logie i Skolehuset i Trondenæs, hvor og saavidt mueligt Alumner gives Boepæl”. ${ }^{26}$ Han bodde på internatet i skolehuset sammen med seminarets elever. Gundersens årslønn var fire ganger så mye som det hver av elevene årlig fikk til reisepenger. ${ }^{27}$ Ut fra bestyrer Kildals uttalelser var dette en god betaling. ${ }^{28}$

Når det gjaldt rekruttering av elevene, viste de første årene seg å være problematiske. Selv om de fikk fritt losji i skolehuset og penger til reise og underhold, var det vanskelig å få søkere. Særlig gjaldt dette Finnmark. I 1825 ble det tatt opp to elever, og seminaret begynte med disse to. Ved slutten av 1827 var der seks elever. Først i 1835 var alle ni plassene besatt, og der var flere aspiranter enn seminaret kunne ta opp. Elevenes alder var mellom 17 og 25 år. Stort sett hadde de en vanlig landsens bakgrunn. Søknad om opptak ble sendt til bestyreren ved seminaret. En slik søknad inneholdt anbefaling av den potensielle eleven, og vedlagt var dåpsattest og attest for at vedkommende var vaksinert mot kopper. ${ }^{29}$ Det var de gode hoder til konfirmasjon som anbefaltes til opptak, men de færreste kom inn på seminaret rett etter konformasjonen. Stor variasjon forekom i forkunnskaper, noen kunne knapt lese. Dette vanskeliggjorde undervisningen. Tilsvarende var det stor variasjon med hensyn til skoleresultater, karakterene lå på et middels nivå.

Vanligvis ble elevene dimittert etter tre år ved Trondenes Seminarium, men også på dette punktet forkom store variasjoner, noen gikk to eller fire år. Etter endt skolegang var de forpliktet til å virke sju år i sitt prosti. Det var kun mannlige elever som ble tatt opp helt til 1886, da første kvinnelige elev var et faktum.

Trondenes Seminarium skulle utdanne lærere og kateketer. Undervisningen ved seminaret de første årene var lite tilrettelagt. Det ble laget et foreløpig reglement i 1827, men forholdene var ustabile, og fra 1834 fulgte Trondenes Seminarium et foreløpig reglement utarbeidet for Asker Seminarium. ${ }^{30}$ Departementet var imidlertid fornøyd med Trondenes Seminarium og de første års virksomhet der, vurdert ut fra skriv i 1831 . Men bestyrer Kildal så seg ikke tilfreds med annenlærer Gundersens undervisning, som han mente var "saare lidet frugtbringende". ${ }^{31}$ Misnøyen gikk ut på at Gundersen hadde for lite kunnskaper, og bestyreren ønsket å få tilsatt en annenlærer med seminaristisk utdannelse. Antakelig var det snakk om en kulturkonflikt. I 1840 fikk

\footnotetext{
25 Dahl (1976), 14.

26 Brev datert 18. juni 1824 fra Trescow, Kirke- og Undervisningsdepartementet, til politimester Lie, SLFA, SAT.

27 Regnskap Seminarii Lapponici Fond 1832-34, som viser at fondet overførte 320 speciedaler til Trondenes Seminarium i 1832 og 300 speciedaler i 1834, SAT

28 Dahl (1976), 14.

29 Søknader om opptak ved Trondenes Seminarium, TOLA, SATØ.

30 Torstein Harbo, Teori og praksis i den pedagogiske utdannelsen: Studier i norsk pedagogikk 1818-1922 (Oslo: Universitetsforlaget, 1969), 50.

${ }^{31}$ Dahl (1976), 14.
} 
Nils Gundersen avskjed i nåde med to tredjedeler av sin pensjon i lønn. Han dro tilbake til Måsøy, der han døde i 1854.

Kvoten av samiske elever viste seg å være vanskelig å få oppfylt. Våren 1827 ble den første samiske eleven tatt opp. Han kom fra Sør-Varanger. Høsten 1827 ble nok en samisk elev tatt opp. Han kom fra Karasjok. De samiske elevene hadde svært varierende forkunnskaper. I løpet av den tiden seminaret holdt til på Trondenes, fra 1826 til 1848, ble totalt ni samiske elever og en kvensk elev tatt opp.

BILDE 2. Dokument som viser de to første samiske elevene ved Trondenes Seminarium, 1827 (disse har ordet Lap tilføyd i parentes etter navnet)

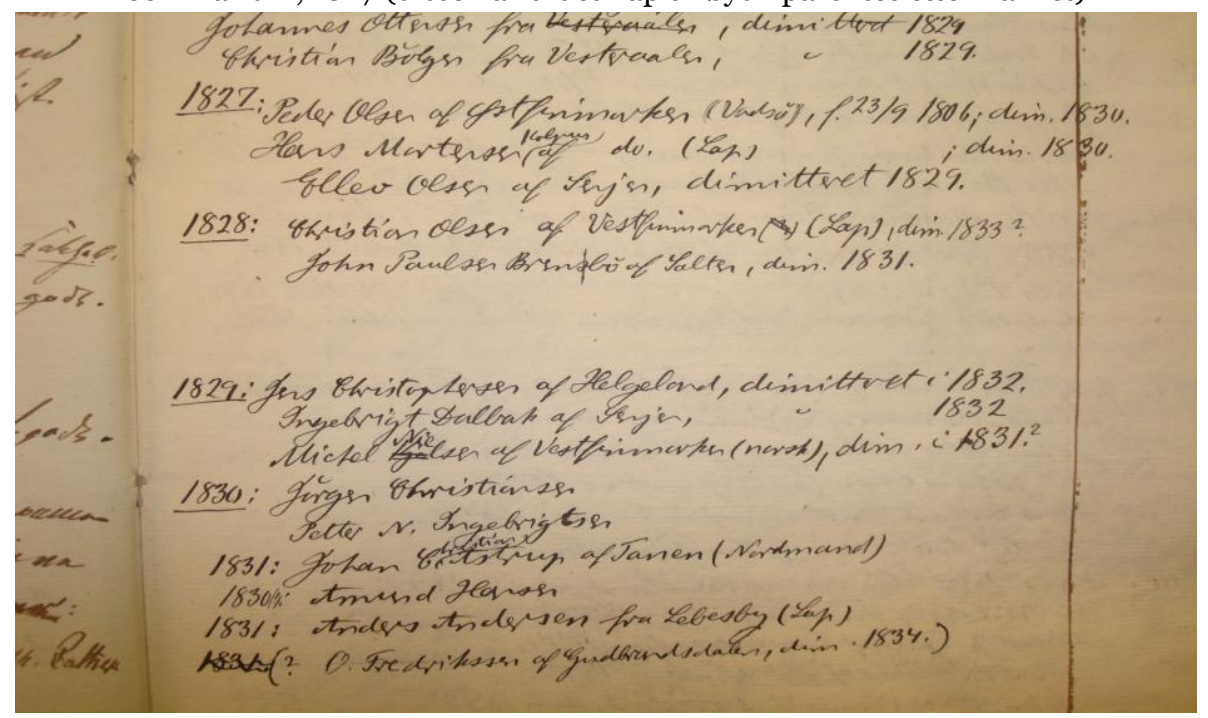

Kilde: Statsarkivet i Tromsø, Tromsø offentlige lærerskoles arkiv

Etter hvert vokste det fram et behov for å øke antallet elever ved seminaret, og med det også et behov for flere lærere. En tredjelærer ble tilsatt i 1836, og da kunne seminaret ta opp 20 elever. Om mulig skulle fire av disse være samisktalende.

Fagene ble fordelt på følgende måte de første årene. Bestyrer skulle ha religion på norsk, kateketikk og norsk grammatikk. Annenlærer skulle ha skriving og regning, samisk for de samiske elevene og dem av de norskfødte som kunne forvente å bli tilsatt i distrikter der det bodde samiske familier. Det kom ny skolelov 1827, og etter det ble geografi og Norgeshistorie innført ved seminaret i 1829. Når det gjaldt praksisfeltet, ble det i løpet av seminarets første år praktisk øving på konfirmanter. Fra 1833 av var det praksis på fast skole med 50 barn, men denne ordningen varte kun 3-4 år. BellLancaster-metoden var i bruk på 1830-tallet. Den hadde som prinsipp at en del av undervisningen skulle utføres av de eldste elevene. Av pensum som ble lest, kan nevnes Lyder Sagens lesebok og danske stilebok, utdrag av Badens danske grammatikk, Herslebs større bibelhistorie, Fayes lærebok i fedrelandshistorie og Platous mindre lærebok i geografi. Bestyrer Kildal var selv lærebokforfatter. Han gav ut lærebok i 
religion for konfirmanter samt en ABC-bok som var meget moderne lagt opp med henblikk på lesemetode. ${ }^{2}$

De økonomiske forholdene ved seminaret viste snart at finansieringen fra Seminarrii Lapponici Fond ikke var tilstrekkelig til drift og lønninger. Årlig beløp sendt seminaret på begynnelsen av 1830-tallet lå på rundt 300 speciedaler. 33 Når man tar i betraktning at annenlærers lønn var på 200 speciedaler og reisepenger for hver av elevene lå på 50 speciedaler, blir det klart at andre finansieringskilder var nødvendig. Mot slutten av 1820-tallet kom Opplysningsvesenets fond inn i bildet og overtok det meste av finansieringen i 1836 .

Selve de fysiske forholdene, skolebygningen, var ikke mye å rope hurra for da seminaret startet. Bygget lå like ved Trondenes kirke. Det var en 200 år gammel bygning med 62 kvadratmeter grunnflate. Bygningen inneholdt to rom, kjøkken, gang og takkammer. Klasserommet var nede, et rom på 32 kvadratmeter og 2 meters høyde. Oppe på takkammeret var det soverom med skråtak, 2 meter på høyeste punkt og ingen ovn. Det var dårlig standard på dette rommet; snø føk inn vinterstid og det var rotter der.

BILDE 3. Den første skolebygningen, Trondenes Seminarium, beliggende ved siden av Trondenes kirke

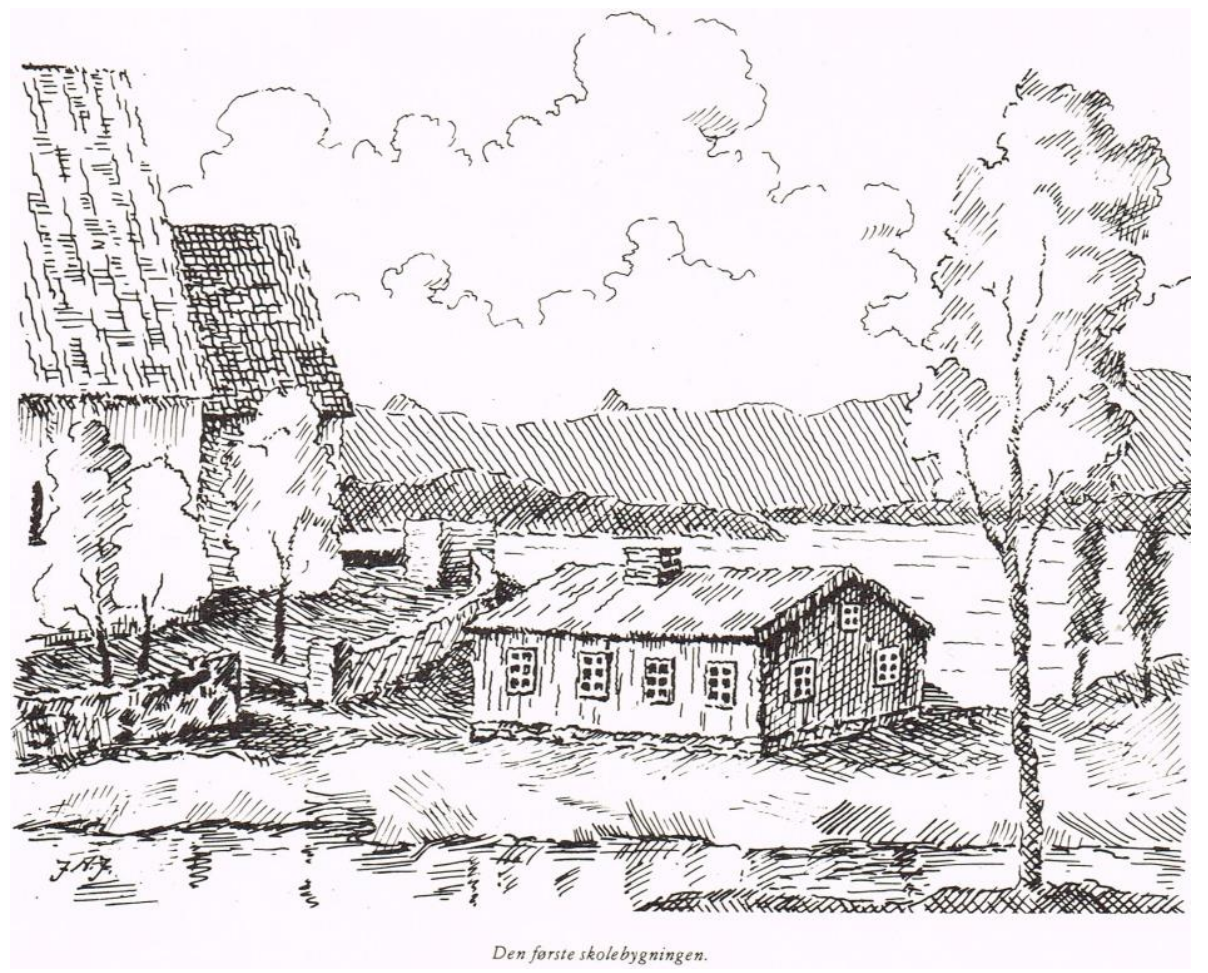

Fra Helge Dahl, Tromsø offentlige lærerskole i 150 år, s. 15

32 ABC-en var disponert i henhold til progresjon i innlæring av konsonanter og vokaler i definerte grupper, noe som resulterte i at elevene lærte å lese enkle ord hurtig.

33 Regnskap Seminarii Lapponici Fond 1832-34, SAT. 
Mat og stell måtte elevene sørge for selv i løpet av seminarets første år. Selv om elevene hadde fritt losji i skolebygningen, hadde de utgifter til innkjøp av mat, og de måtte sørge for å få tak i den billigste maten. Ofte måtte de fare langt av sted for å kjøpe inn naturalia fra bønder i omegnen eller dra på ekspedisjoner til handelssteder i nærheten. En kone som skulle ta seg av renhold, klesvask og matlaging ble ikke tilsatt før 1832. Seminaret ble driftet innen slike rammer i 10 år, og det ble stadig mer påtrengende å få større plass og bedre sanitære forhold. I 1836 skjedde det en utvidelse gjennom Kongelig resolusjon. Ny skolebygning skulle bygges.

\section{Seminarets grunnsatser og videre forløp}

Grunnsatser i det nye lærdomsmiljøet på Trondenes var utvelgelse av elever innen kirkelig struktur, ivaretakelse av etniske forhold i nord, ansvar for faglighet og drift lagt til sognepresten, siktemål skole og kirke gjennom utdannelse til lærer og kateket, ivaretakelse av morsmålets primat ved undervisning på norsk og samisk, vektlegging av dannelsesaspektet i undervisningen samt gradvis ekspansjon av lærerstab, elevgruppe og fagportefølje.

De første årene var fulle av utfordringer av faglig så vel som praktisk karakter. Seminaret ble overført til Tromsø i 1848, og den ilddåp som skjedde de første årene på Trondenes, var da overstått. Trondenes Seminarium utviklet seg videre og ble en bastion for kunnskap og høyere utdanning i Nord-Norge. Seminaret som startet på Trondenes, har hatt stor betydning for mulighet til lærerutdannelse ikke bare for samiske ungdommer, men også for norske ungdommer i den nordlige delen av Norge. Trondenes Seminarium flyttet sin virksomhet til Tromsø i 1848, og fikk navnet Tromsø offentlige lærerskole. Lenge var det slik at samiske og norske lærere fikk utdannelse ved samme institusjon. Slik utviklingen har gått fram mot årtusen skiftet 2000, er samisk og norsk sidestilte språk i Norge og egne samiske institusjoner for høyere undervisning har utviklet seg. Blant annet utdanner Samisk høgskole i Kautokeino lærere som skal virke i samiske områder, der samisk er hovedspråk i skolen. Tromsø offentlige lærerskole ble fusjonert med andre institusjoner til Høgskolen i Tromsø i 1994. Denne institusjonen ble i 2009 en del av Universitetet i Tromsø.

\section{Avspeiling av større strukturer}

En mikroundersøkelse av et lærdomsmiljø, slik den er foretatt her, avspeiler større strukturer. Den sier noe om kirkelig og statlig innflytelse. Den viser samspillet mellom det nasjonale og det regionale. Den viser sammenhengen mellom det regionale og det lokale.

Når en utdanningshistorisk case study her hevdes å avspeile større strukturer, er det fordi den peker mot forhold og aktører i et nasjonalt og internasjonalt bilde som setter sine spesifikke avtrykk på en etablering av regional og lokal karakter. I interaksjon mellom strukturrelaterte overordnede mekanismer og regionalt initiativ reiser Trondenes seg som en nyskapning influert av historiske faktorer i kombinasjon med samtidig utdanningshistorisk tankegods.

Avspeilingen av større strukturer ved etableringen av Trondenes Seminarium i 1826 kan sees ved nedfelling av relasjonelle direktiver og konstellasjoner på statlig nivå etter at Norge fikk sin grunnlov i 1814 og den langvarige unionen med Danmark var opphørt. Et stort statlig ansvar gjorde det nødvendig å iverksette planmessig arbeid som skulle dekke alle statens forpliktelser, inkludert utdanning på alle nivåer. Den nyvunne frihet 
bidro til nytenking og tydeliggjøring av målsettingen for kunnskapsformidling og strategisk oppbygging av denne i det ganske land. I sin bok Maktens korridorer: Regjeringskontorene 1814-1940 påpeker Ole Kolsrud ved å vise til arkivers organisering hva slags grep som ble foretatt etter 1814 når det gjaldt organisering av statlig forvaltning. Han sier:

Utviklingen av kirke- og undervisningsdepartementet preges av to hovedtemaer. Det ene temaet er en prioritetsdreining fra kirkesektoren til skolesektoren. Det andre temaet er en prioritetsdreining fra det økonomiadministrative til det kulturadministrative. Det siste temaet veksler mellom faser av ekspansjon og faser av kontroll og innsparing. 34

Det første temaet peker i retning av gradvis mindre innflytelse fra kirken i skolespørsmål. Det andre temaet peker i retning av skolens finansielle situasjon, der blant annet salg av kirkens benefiserte jordegods ble gjennomført fra 1821 og utover. 35 Jeg vil i det følgende drøfte litt nærmere hvordan etableringen av Trondenes Seminarium rent konkret avspeiler de omtalte større strukturer og vil først gå inn på den relative innflytelse fra kirke og stat.

Utdanningshistorisk var tiden etter at Norge fikk sin grunnlov, preget av konsolidering av de to fundamentale faktorer innen utdanningssektoren, nemlig kirke og stat. Dette gjaldt ikke minst den tidlige lærerutdanningen. Kirken og dens aktører hadde hatt en fremtredende rolle under den preliminære fase av norsk lærerutdanning, eksemplifisert ved de to tidligste seminarer i Trondheim for utdanning av misjonærer, kateketer og lærere for det nordlige Norge, ledet av Thomas von Westen (1682-1727). Denne tidlige oppstarten til lærerutdanning i Norge er grundig drøftet av Randi Skjelmo i artikkelen "Utdanning av lærere for det nordlige Norge. De tidlige institusjoner i Trondheim 1717-1732". ${ }^{6}$ Skjelmo går grundig inn på seminarene Seminarium Scholasticum og Seminarium Domesticum, som eksisterte i perioden 1715-1727, og påpeker disse tidlige seminarers betydning for det senere Seminarium Lapponicum i Trondheim, ledet av Knud Leem (1696-1774). Men særlig understreker Skjelmo betydningen av de to første seminarene for etablering av et skolevesen i Norge etter at unionen med Danmark var opphørt.37 Under etableringen av disse tidlige seminarer i Trondheim var kirken gjennom Missions-Kollegiet i København og biskopen i Nidaros en viktig premissleverandør med henblikk på innhold og organisering. Imidlertid avtok kirkelig innflytelse på utdanningsfeltet etter hvert, noe Randi Skjelmo drøfter i sin doktoravhandling fra 2007, Endringer $i$ norsk allmennlærerutdanning: Mot en sterkere enhetlighet. ${ }^{8}$ Skjelmo påpeker at skolelærerseminarer av typen prestegårdsseminarer ikke fikk fotfeste i Norge og at veien gikk i retning av opprettelse av stiftsseminarer. Ifølge Lov angaaende Almueskolevæsenet paa Landet av 1827 lagt under regjeringen, var det denne som hadde plikt og fullmakt til å sette i gang

\footnotetext{
34 Ole Kolsrud, Maktens korridorer: Regjeringskontorene 1814-1940 (Oslo: Universitetsforlaget, 2001), 198-99.

35 Kolsrud ( 2001), 200.

36 Skjelmo (2013), 39-62.

37 Skjelmo (2013), 39.

38 Randi Skjelmo, Endringer i norsk allmennlærerutdanning: Mot en sterkere enhetlighet (Tromsø:

Universitetet i Tromsø, 2007).
} 
seminarer så snart finansielle forhold tillot det. "Det var regjeringen som skulle bestemme antall, sted og varighet, fag, ansettelse av lærerkrefter og lønn, mens stiftsdireksjonen skulle komme med tilråding."39

I stedet for en tung kirkelig innflytelse i utdanningssektoren ser man etter 1815 omrisset av en skolesektor - i vårt tilfelle en offentlig nasjonal lærerutdanning - som er influert og inspirert av et pedagogisk idéhistorisk tankegods fra Europa. Disse idéene kom via den første danske lærerutdanningsinstitusjon, Blaagard Seminarium, og fikk avgjørende betydning for det som skjedde av utviking i dette feltet i Norge. Det var snakk om å utforme en nasjonal utdanningssektor der pedagogisk tenkning var i forsetet og der nødvendige hensyn til regionale og lokale forhold internt i Norge ble ivaretatt. Man stod overfor en nasjonal utfordring, der avgjørende bestemmelse ble tatt av nasjonens folkevalgte organ, Stortinget, men der viktige innspill kom fra regionene gjennom valgte representanter til nasjonalforsamlingen. I vårt eksemplariske kasus kan vi knytte direkte an til den debatt som forgikk på Stortinget i forkant av etableringen av Trondenes Seminarium, der representanten Deinboll fra Finnmark var en av de sterkeste pådriverne for opprettelse av offentlig lærerutdanning. Hans argumentasjon var både av generell karakter og av spesiell karakter, basert på hva som var formålstjenlig for landets nordligste del. Som vist ovenfor, førte denne argumentasjonen fram. I tillegg er det viktig å notere seg at etableringen av Trondenes Seminarium skjedde året før folkeskoleloven av 1827, en lov som satte opp retningslinjer for hva slags skolegang gutter og jenter over det ganske Norge skulle ha. ${ }^{40}$ Samspillet mellom det nasjonale og det regionale aksentueres, som vist tidligere i denne artikkelen, i diskusjonen på Stortinget i perioden 1814-1826, da momenter ikke bare knyttet til nordlig og sørlig del av Norge, men også til etniske forhold i nord, ble brakt inn i debatten.

Metodologisk knytter denne artikkelen seg til Margaret Archers teorigrunnlag om framveksten av statlige utdanningssystemer, som tidligere har blitt brukt i en nordisk utdanningshistorisk kontekst av blant andre Randi Skjelmo i hennes doktoravhandling fra 2007. Teoretisk argumenteres det klart i retning av å se statlig initierte rammefaktorer som strukturelt bærende elementer. En modell lanseres der det nasjonale og det regionale i interaksjon innlemmes i forskningsfeltet utdanningshistorie. ${ }^{41}$ Knyttet opp mot kasus Trondenes Seminarium viser dette teoretiske anknytningspunktet seg relevant. Man er rundt $1826 \mathrm{i}$ en fase utdanningshistorisk der det er naturlig å snakke om et overordnet strategisk grep fra statlig hold som skal være til gavn for hele Norge. Ut fra ønsket om å skape en obligatorisk kunnskapsbase for hele nasjonen skapes det rom for aktører med et bestemt mandat i ryggen som trer inn i nasjonale faglige diskusjoner, aktører som forfekter synspunkter ut fra regionalt og lokalt perspektiv, men på en nasjonal arena.

Etableringen av Trondenes Seminarium er et glimrende eksempel på at aktører relatert til skolesektoren på nasjonalt nivå vinner fram med argumentasjon som inkorporerer regionale interesser og lokal plassering av utdanningsinstitusjon. Interessant nok spiller etniske forhold samt økonomiske forhold en vesentlig rolle ved etableringen av Norges første offentlige lærerutdanning. Dette framhever betydningen

\footnotetext{
39 Skjelmo (2007), 64 .

40 Skjelmo (2007), 63-64; Hans-Jørgen Dokka, Fra allmueskole til folkeskole (Oslo: Universitetsforlaget, 1967), 31, 34 .

${ }^{41}$ Skjelmo (2007), 24-40.
} 
av pragmatiske faktorer som kan fă gjennomslagsverdi. Det er snakk om et stort og komplekst samspill for at ønsket om den første lærerutdanning i Norge skal bli en realitet. Men over de regionale og lokale innspill er det reist en overbygning av statlig art, ellers ble de regionale initiativ å regne for intet.

\section{Avslutning}

I denne artikkelen kommer det klart fram hva som ble de praktiske utfordringene regionalt og lokalt da Trondenes Seminarium skulle settes i gang. Likevel hviler alle muligheter for regional og lokal implementering av institusjonens virksomhet på det vedtaket som ble gjort i Stortinget tidlig på 1820-tallet. Dermed må oppstarten etter min oppfatning sees i lys av mer overgripende strukturer og aktører som beveger seg på nasjonalt plan. Skinningsrud argumenterer i sin avhandling for en framvekst av utdanningssystemet etter reformasjonen der skolen var dualt integrert med kirke og stat. ${ }^{2}$ Denne artikkelens lille dykk ned i forhistorien til Trondenes Seminarium og institusjonens første år i drift synes å understøtte et slikt argument. Seminarets formål, dets foreslåtte struktur for utvelgelse av elever, dets foreslåtte innhold og de preliminære stadier av institusjonens tilblivelse bygger opp under en fortolkning av seminarets oppstart som et samspill mellom skole, kirke og stat både på nasjonalt og regionalt plan. Det er tydelig at statlige strukturer har hatt stor betydning for gjennomføring regionalt og lokalt. Artikkelen viser det møysommelige strevet for å få et nasjonalt vedtak om etablering på plass. Deretter kommer problematikken med å bygge opp en holdbar faglig standard på en geografisk marginalt plassert institusjon. En vurdering av det relative styrkeforholdet mellom de ulike nivåer som var involvert i etableringen av Trondenes Seminarium, peker i retning av strukturelle forhold på nasjonalt nivå som meget avgjørende for at Norge fikk sin første lærerutdanning nord i landet. Når det gjaldt den praktiske virksomheten harmonerte ikke alltid realiteter og idealer, men utfordringene ble overvunnet over tid og den nyfødte institusjonen viste seg å ha livets rett.

42 Skinningsrud (2013), 462-64. 


\section{Referanser}

Barlindhaug, K. J. Tromsø offentlige lærerskole i 100 år. Tromsø: AS Peder Norbyes bok \& aksidenstrykkeri, 1926.

Biskopen i Tromsø Stifts arkiv (BTSA), Statsarkivet i Tromsø (SATØ).

Brekke, Mary. Lærerutdanning i Nord: Et historisk kasus gjennom tre tidsperioder. Luleå: Luleå tekniska universitet, 2000.

Dahl, Helge. Tromsø offentlige lærerskole i 150 år: 1826-1976. Jubileumsskrift. Tromsø: AS Peder Nordbyes trykkeri, 1976.

Dokka, Hans-Jørgen. Fra allmueskole til folkeskole. Oslo: Universitetsforlaget, 1967.

Harbo, Torstein. Teori og praksis i den pedagogiske utdannelsen: Studier i norsk pedagogikk 1818-1922. Oslo: Universitetsforlaget, 1969.

Hoëm, Anton. Fra noaidiens verden til forskerens: Misjon, kunnskap og modernisering i sameland 1715-2007. Oslo: Novus forlag, 2007.

Killengreen, J. Beretning om Tromsø Seminarium meddelt ved Seminariets halvhundreaarsfest den 7de Februar 1876. Tromsø: Carl Hansens Bogtrykkeri, 1876.

Kolsrud, Ole. Maktens korridorer: Regjeringskontorene 1814-1940. Oslo: Universitetsforlaget, 2001.

Kontoret for kirke og geistlighet A 1821-1835, eske 986, Kirke- og Undervisningsdepartementets arkiv (KUDA), Riksarkivet (RA).

Rasmussen, Tarald. "Mathias Bonsach Krogh.” Store norske leksikon, nettutgave, nedlastet 20.01.2011.

Seminari Lapponici Fonds arkiv (SLFA), Statsarkivet i Trondheim (SAT).

Skinningsrud, Tone. Fra reformasjonen til mellomkrigstiden: Framveksten av det norske utdanningssystemet. Tromsø: Universitetet i Tromsø, 2013.

Skjelmo, Randi. Endringer i norsk allmennlærerutdanning: Mot en sterkere enhetlighet. Tromsø: Universitetet i Tromsø, 2007.

Skjelmo, Randi. "Utdanning av lærere for det nordlige Norge: De tidlige institusjoner i Trondheim 1717-1732." Sjuttonhundratal: Nordic Yearbook for EighteenthCentury Studies (2013), 39-62.

Skjelmo, Randi. "Utdanning av lærere for det nordlige Norge før 1826: Tidlige nordiske institusjoners betydning som forløpere for offentlig lærerutdanning." I Norrlandsfrågan: Erfarenheter av utbildning, bildning och fostran i nationalstatens periferi, red. Johannes Westberg och David Sjögren. Stockholm, 2014, kommer.

Wiig, Christian. Tromsø-seminarister: Biografiske oplysninger om seminarister som er dimittert fra (Trondenes og) Tromsø seminar. 1829-1879. Oslo: Land og kirke, 1948.

Willumsen, Liv Helene. "Økonomiske vilkår for lærerutdanning i nordlige Norge: Den historiske utvikling av Seminarii Lapponici Fond.” I Norrlandsfrågan: Erfarenheter av utbildning, bildning och fostran i nationalstatens periferi, red. Johannes Westberg och David Sjögren. Stockholm, 2014, kommer.

Tromsø offentlige lærerskoles arkiv (TOLA), Statsarkivet i Tromsø (SATØ). 